\title{
Bilateral incudomalleolar dislocations: an unusual cause of deafness
}

\author{
Michael Paddock, ${ }^{1}$ Timothy Hodgson, ${ }^{2}$ Dev Bhattacharyya ${ }^{3}$
}

${ }^{1}$ Academic Unit of Radiology, University of Sheffield, Sheffield, South Yorkshire, UK ${ }^{2}$ Department of Neuroradiology, Sheffield Teaching Hospital NHS Foundation Trust, Sheffield, South Yorkshire, UK ${ }^{3}$ Department of Neurosurgery, Sheffield Teaching Hospital NHS Foundation Trust, Sheffield, South Yorkshire, UK

\section{Correspondence to} Dr Michael Paddock michael.paddock@doctors.org. uk

Accepted 17 February 2017
CrossMark

To cite: Paddock M,
Hodgson T, Bhattacharyya D.
BMJ Case Rep Published
online: [please include Day
Month Year] doi:10.1136/
bcr-2016-218733

\section{DESCRIPTION}

A 57-year-old woman was seen in an outpatient neurosurgery clinic after reporting daily headaches, a 'whooshing and squelching' sound in her head and reduced hearing in her left ear. Three months' prior she required admission following serious head trauma. Imaging at that time revealed multiple skull fractures with extra-axial haemorrhages. Follow-up thin section CT of the petrous temporal bones (figure 1) demonstrated bilateral incudomalleolar dislocations. Ossicular chain disruption can

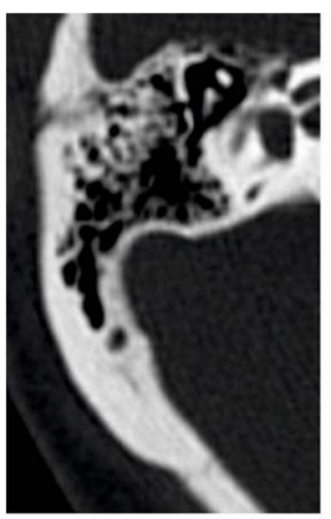

Right

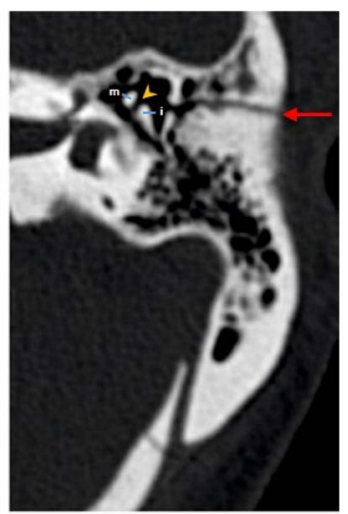

Left
Figure 1 Cropped images of the left and right inner ear ossicles from an axial thin section CT scan through the petrous temporal bones demonstrating bilateral incudomalleolar dislocations (only left side labelled). i, incus; $\mathrm{m}$, malleus; Orange arrow head, incudomalleolar dislocation; Red arrow, fracture line through left mastoid bone. be easily overlooked and thorough assessment of the middle ear should be performed on follow-up imaging, particularly considering persistent patient symptoms.

At initial follow-up, the patient reported persistent headaches, tinnitus and bilateral decreased hearing loss, worse on the left. Formal audiological testing revealed a left-sided deficit which was corrected with a hearing aid. Further follow-up revealed no change in hearing and resolution of her headaches.

\section{Learning points}

- The normal appearance of the malleus and incus is that of a 'scoop of ice-cream' (malleus) sitting in an 'ice-cream cone' (incus).

- Incudomalleolar dislocation is diagnosed on imaging when the 'ice-cream' has fallen off the 'cone'.

- The configuration of the ossicular chain should be actively sought when reviewing and reporting imaging.

Contributors MP reformatted, labelled and prepared the images for publication; wrote the text and figure legend. TH reported the scan; extracted images; reviewed the manuscript. DB reviewed the patient in outpatient clinic; obtained informed written consent; reviewed the manuscript.

Competing interests None declared.

Patient consent Obtained.

Provenance and peer review Not commissioned; externally peer reviewed.

Copyright 2017 BMJ Publishing Group. All rights reserved. For permission to reuse any of this content visit http://group.bmi.com/group/rights-licensing/permissions.

BMJ Case Report Fellows may re-use this article for personal use and teaching without any further permission.

Become a Fellow of BMJ Case Reports today and you can:

- Submit as many cases as you like

- Enjoy fast sympathetic peer review and rapid publication of accepted articles

- Access all the published articles

- Re-use any of the published material for personal use and teaching without further permission

For information on Institutional Fellowships contact consortiasales@bmjgroup.com

Visit casereports.bmj.com for more articles like this and to become a Fellow 